昨年の第 1 回の學會で, 運動能烄查の閥題の選

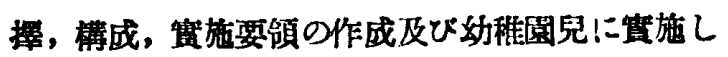
た結果の吟味に就て侮表したが，更に幼稚園兒並 びに小學校校低年 (1 年 3年)の資料を加え

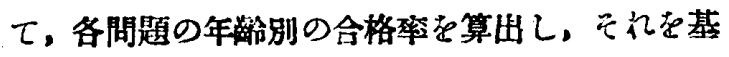

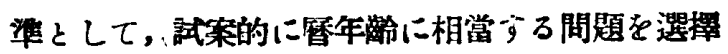
した.

55 種目では間題數が餘りに多く，これを個別的 に检查していては，資料蒐集にる困難存件うので，

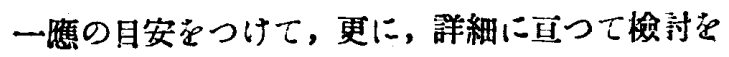

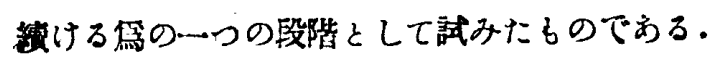

\section{6. 等生徒と正学生徒との通功能の對比}

\section{情州大祭声拏部 山丙成量}

体育運動指䢙の䚈點から端生徒に對し，正常者 に比較して，特に留意すべき篮を見出さんとして， 起轉跳躍, 反轉跳櫂、リーチジャンブ, 立巾跳, バービーテスト，背腔力等を調查し，正常者のそ れ等と比較检討した一部を報告する。

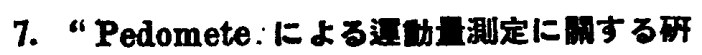 究（第一報）}

\section{北海道大學 奈辰岡 健三}

運動の量 $と$ 質が簡明に数字的に表示し得るなら は体育の現表面に大きな貝献をすることになるで おろうと考え，その一部若數量で表はすことが出 來るを思はれる Pedometer (步數咶) 使用し

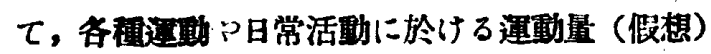
を测定研究することにより，

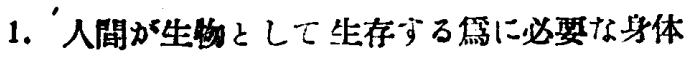
活野量の最低・最高限界积の矠想・推定

2. 体育の篇の各稉運動競技の量 $z$ 質の洞題

3 体育方法上の学考資料

等の究明を試みるのが本研究の主要目標であ 3 .

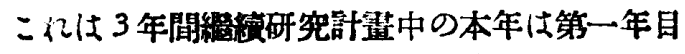

で，今回の墢表は中間報告に止まる。

8. Leap-meter (リープ・メーター) の教案 にっいて

東京教育大學体有㩆部

松井三椎・会田砦男
交
部
雀 字土正应

垂直跳は基碟的な運動能力として，各種琿動の 成就の程度を预測し得るるのとして，重要なるの であり、我が國でる，ての測定が㯕く行りれるよ うになつた。

普通に使用されている方法は，壁の上に張られ た紙の上に、チョークで印苍つける所謂チョーク ・ジャンプによる方法であり，にの湘定の客嚾性 を得るのに困難が台ると思われる。また他の運動

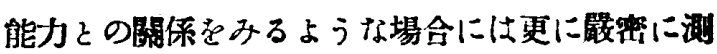
定する必要に迫られる。これらの要求它滿すと共， に，多人數の者を短時間で，簡單に测定し得るた めに“リープ・メーター”考案した。チョーク

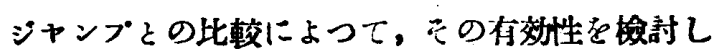
た結果営發表する。

\section{9. 分散分析法について}

\section{金賟大學 佐々木 茂}

珫計的研究法の一つをしての分散 (繁量) 分 析法の体育の間題解決に用いる坦合の二，三 の間題につけて

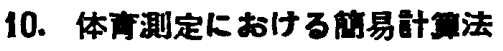

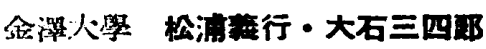

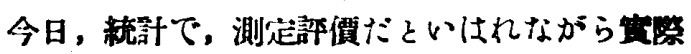
には，現場では殆えど行はれていない。

その原因の一つは，計算のやつがにとのた めに，一般に行はれないのではないかと考一られ

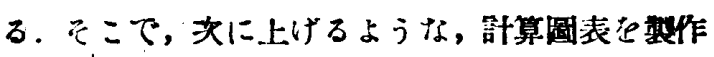
して見た。
1. $\mathbf{R}=\frac{\mathrm{W}}{\mathbf{H}^{-} \times 100}$ 2. $\mathbf{T}=17.5 \mathrm{~A}+2 \mathrm{H}+2 \mathrm{~W}$
3. $\mathrm{T}_{2}=2 \mathrm{H}+2 \mathrm{~W}$ 4. $\mathrm{T}_{3}=8.75 \mathrm{~A}+2 \mathrm{~W}$
5. $\mathrm{F}_{\mathrm{U} . \mathrm{D}}=3.54 \mathrm{~W}+3.42 \mathrm{~N} \cdot \mathrm{N}-46$
6. $\mathrm{F}_{\mathrm{U}}=1.34 \mathrm{~W}+1.2 \mathrm{~N}_{\mathrm{C}}+52$
7. G.M.C.S. 四式 8. T スコY
9. $T=17.5 \mathrm{~A}+2 \mathrm{H}+2 \mathrm{~W}+\mathrm{S}$
10. $\mathrm{T}=8.75 \mathrm{~A}+2 \mathrm{~W}+\mathrm{S}$

\section{1. 砲丸投飔合度做定}

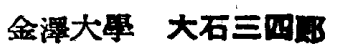

